\title{
KISAH DAN MATERI DAKWAH NABI HUD
}

\section{Sutrisno Sutrisno}

Pascasarjana Universitas Islam Negeri Sunan Kalijaga Yogyakarta Email: ibn.udien@yahoo.com

\section{Abstract:}

Prophets and messengers have the same role, that is, to bring the teachings of monotheism. However, their exposure of tawhid varies, adjusted to the level of thinking maturity of their people. Hud is a prophet and messenger sent to the people of 'Ad. They lived in Al-Ahqaf (the Sandy Plains) and built countless buildings that had never been before. They had superior civilization and skills in such fields as agriculture, livestock breeding, and architecture. The arrival of Hud was not appreciated, but insulted and mocked. They are repeatedly reminded to return the Oneness of Allah and to abandon idolatry, but only a few of those who accept it. Finally, they were persecuted, and their civilization was destroyed. An archeologist did the research in 1990 and found the ruins believed to be the pillars of building that was formerly owned by the people of Aad 'and Iran. This story has been told in the Quran in several Surah, its substance and value are permanently maintained. However, its impression and lessons are different.

$$
\begin{aligned}
& \text { كان الأنيياء والمرسلون لمم نفس الدور ، أي تحقيق تعاليم التوحيد. ومع ذلك، فإن تعرضهم للتوحيد }
\end{aligned}
$$

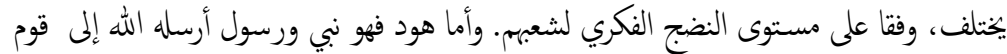

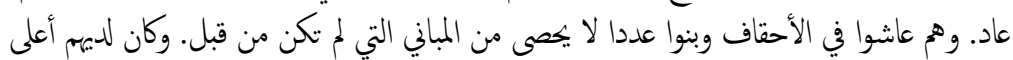

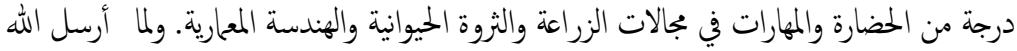

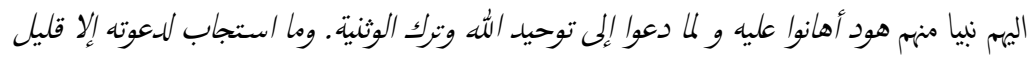

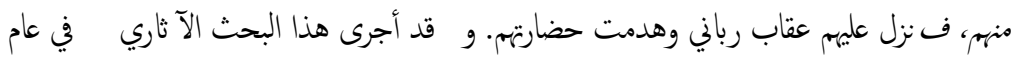

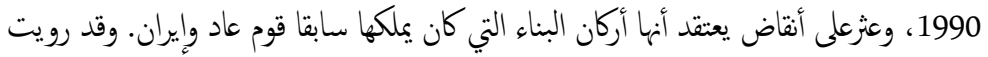

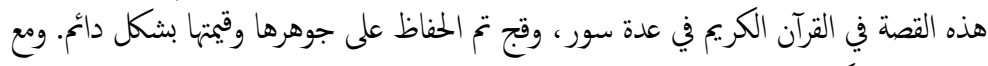

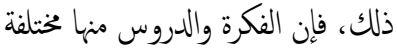


Kata Kunci: kisah, nabi Hud, kaun Aad, materi dakwah

\section{A. Pendahuluan}

Hud $^{1}$ adalah Nabi dan Rasul Allah adalah utusan Allah kepada umat manusia yang berperan untuk menyampaikan pesan-pesanNya (pembawa berita), baik untuk periode dan masyarakat tertentu maupun untuk seluruh manusia di setiap waktu dan tempat. Jumlah mereka secara pasti tidak diketahui. Alquran hanya menginformasikan bahwa tiada satu umat kecuali telah diutus kepadanya seorang pembawa peringatan (Fatir (35): 24). Dan peringatan yang dimaksudkan adalah tentang ajaran tauhid, sebagaimana yang disebutkan dalam QS. Al Anbiya' (21): 25. Pengutusan seorang Nabi dan Rasul merupakan bentuk rahmat dan kemurahan Allah kepada hambanya, karena tidak semua dari hambanya dapat berhubungan langsung denganNya dan memperoleh informasi yang pasti tentangNya. Sementara setiap hamba dituntut untuk merasakan wujud tuhan yang mengantarkan pada ketauhidan dan ketuhanan yang benar. Kendatipun sebenarnya pada setiap diri seorang hamba telah dianugerahi dalil ketuhanan sebagai manifestasi dari kefitrahan manusia, hanya saja seorang hamba terkadang mengikuti ego dan nafsunya sehingga dalil dan fitrah itu tidak terberdayakan.

Ketuhanan dan ketauhidan merupakan prinsip dasar pada semua agama samawi yang dibawa oleh para nabi dan rasul Allah. Pemaparan prinsip tauhid kepada mereka berbeda-beda, disesuaikan dengan tingkat

${ }^{1}$ Namanya adalah Hud bin Selah bin Arpakhsad bin Sam bin Nuh. Namun ada juga meriwayatkan bahwa nama Hud sebenarnya adalah Eber bin Saleh bin Arpakhsad. Ada juga yang meriwayatkan bahwa namanya adalah Hud bin Abdullah bin Rabah bin Jarud bin Ad bin Aus bin Iram bin Sam bin Nuh. (lihat Kisah para Nabi (terj. Dari Qishashul Quran). Karya Ibn Kasir. Beliau menukil riwayat itu dari Ibn Jarir at Tabari. h. 151 
kedewasaan berpikir umat mereka. Oleh karena itu, hampir tidak ada bukti logis yang dikemukakan oleh nabi Nuh kepada umatnya, demikian juga pada masa nabi Hudpemaparan kepada umatnya tidak jauh beda dengan sebelumnya, hanya saja disertai dengan peringatan tentang nikmat-nikmat Allah yang mereka dapatkan, kemudian berlanjut pada nabi Shaleh pemaparannya sedikit lebih luas dan lebih rinci, karena wawasan umatnya lebih luas pula, maka diingatkanlah tentang asal kejadian dan tugas mereka. Sedangakan pada masa nabi Shaleh pemaparan tauhid bukan hanya dikaitkan dengan bukti-bukti, tetapi juga dirangkaikan dengan hukum-hukum syariat. Pemaran berbeda yang berlaku pada masa nabi Ibrahim yang sudah mulai meningkat kedewasaan umatnya, hal tersebut juga tidak terlepas dari pembinaan dan penemuan nabi Ibrahim sendiri melalui pencarian dan pengalaman kerohanian yang dilaluinya yang berkaitan dengan apa yang diketahuinya dan yang tidak diketahuinya, berkaitan dengan kedudukannya sebagai makhluk, dan hubungan makhluk ini dengan tuhan, alam raya dan makhluk sesamanya. Hingga kematangan itu mencapai puncaknya pada masa nabi Muhammad Saw yang diutus kepada seluruh manusia. ${ }^{2}$

\section{B. Materi Dakwah dalam Peristiwa dan Hikmah}

1. Kaum Pertama Penyembah Berhala Setelah Bencana Banjir

Salah satu dari aturan Allah yang berlaku bagi kehidupan para nabi dan utusannya, bahwa jika hamba-hambaNya telah berada dalam situasi menyimpang, telah jauh berada dalam kehidupan yang tersesat dari ajaran-ajaran agama yang dibawa oleh nabi-nabi Nya, maka 
diutuslah seorang nabi atau rasul baru yang bertugas untuk memurnikan kembali ajaran-ajaran nabi yang sebelumnya, mengembalikan masyarakat yang sudah tersesat ke jalan lurus dan mensucikan jiwa manusia dari segala perbuatan syirik dan menggantinya dengan iman tauhid dan aqidah yang sesuai dengan fitrah dan bawaan manusia.

Setelah peristiwa banjir besar, Nabi Nuh dan pengikutnya menyebarkan keturunannya di bumi. Berabad-abad lamanya bumi menjadi tempat yang aman tenteram bagi manusia dan segala makhluk. Tidak ada manusia yang hatinya ingkar kepada Allah. Setan pun berkeluh-kesah karena menganggur tidak bisa berbuat apa-apa. Semuanya memuja, bertasbih mengagungkan Allah yang menciptakan mereka. Akan tetapi setelah nabi Nuh wafat, dan manusia sudah berkembang menjadi berbangsa-bangsa,mereka telah lupa wasiat Nuh, mereka kembali berbuat jahat dengan mengingkari kekuasaan Allah dan mempersekutukannya dengan menyembah berhala ${ }^{3}$. Bumi kembali merintih karena kezaliman dan kebodohan manusia, seperti apa yang terjadi pada masa Nuh. Maka kali ini Allah mengutus Hud untuk memperingatkan bangsanya yaitu bangsa Aad. Kabilah ini bertempat tinggal di daerah yang disebut $A$ hqaf ${ }^{\prime}$, yang terletak antara Aman dan Hadramaut, di Jazirah Arab Selatan. Ibu kota kaum Aad adalah Iram, yang mempunya bangunan-bangunan tinggi, yang belum pernah dibangun seperti itu sebelumnya di negerinegeri lain. Kebanyakan mereka tinggal di perkemahan yang mempuyai

\footnotetext{
${ }^{3}$ Berh.a yang mereka sembah berjumlah tiga buah, yaitu Sadd, Samud dan Hera (lihat Ibn Kasir h. 153)

${ }^{4}$ Ahqaf yakni bukit-bukit berpasir di wilayah Yaman, antara Oman dan Hadhramaut, disebuah pemukiman yang menjorok ke laut bernama Syahr, dan nama lembahnya adalah Mughits (lihat Kisah para Nabi, Ibnu Kasir)
} 
tiang yang besar, daerah yang diliputi hamparan gurun pasir yang memanjang di sepanjang pesisir. ${ }^{5}$ Sebagaimana yang disebutkan dalam Surah Al Fajr (89) ayat 6-8

2. Kisah Kaum Ad dalam Alquran

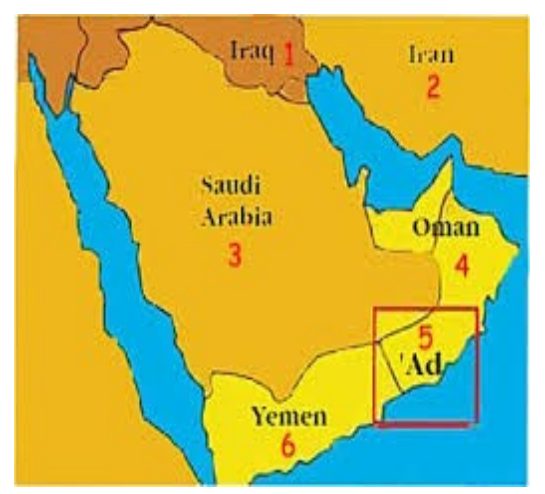

Kaum Aad adalah kaum yang diutus kepadanya nabi Hud. Nama Hud sendiri disebutkan di dalam Alquran sebanyak tujuh kali, yaitu pada surah al A'raf: 65, Surah Hud: 50, 53, 58, 69 dan 89, dan surah as Syuara: 124. Sedangakan kisah kaum Aad dalam Alquran, di ulang pada 17 surah Alquran, dengan tetap mempertahankan tingkah subtansi dan nilai yang setara pada setiap pengulangannya, tetapi kesan dan inspirasi yang ditorehkannya berbeda-beda. Yaitu dengan penambahan kalimat atau pengurangan kata, atau dengan pengungkapan dengan kata-kata baru, atau dengan rangkaian kata yang belum pernah dituliskan pada tempat yang lain. Semua ini dapat mengantarkan pada kesimpulan

${ }^{5}$ K.R.M.T.H Murdodiningrat, Kisah Teladan 25 Nabi dan Rasul Dalam Alquran (Yogyakarta: Pustaka Pelajar, 2012), h. 287 
bahwa yang memaparkan kisah-kisah di dalam Alquran itu bukanlah buatan manusia atau seorang nabi, melainkan disusun oleh Allah Swt. ${ }^{6}$ Adapun ke 17 surah tersebut, diantaranya:

Surah Al Araf ( 7 ) : 65-72, Surah at Taubah (9): 70, Surah Hud ( 11): 5060, Surah Ibrahim (14): 9, Surah Al Mu'minun (23): 31- 41, Surah al Furqan (25): 38-40, Surah as Syu'ara (26): 123-140, Surah al Ankabut (29): 38, Surah Shaad (38): 11-13, Surah Fussilat (41): 12-13, Surah al Ahqaf (46): 21-26, Surah Qaaf (50): 12-13, Surah az Zariyaat (51): 4142, Surah An Najm (53): 50-55, Surah al Qamar (54): 18-21, Surah al Haqqah (69): 6-8, dan Surah al Fajr (89): 6-8.

\section{Situasi Peradaban Kaum Aad Sebelum Hud}

Sebagaimana yang telah disampaikan bahwa kaum Aad adalah kaum penyembah berhala, yang memiliki keahlian dalam berbagai bidang. Dalam bidang agrarian mereka mampu mengelola tanah yang tandus menjadi subur, sehingga cocok tanam sangat memuasakan dan dapat menunjang perekonomian mereka. Dalam bidang peternakan mereka mampu memelihara hewan ternak dengan baik sehingga mendatangkan hasil yang sangat memakmurkan.Namun, kehidupan yang sarat dengan kemakmuran itu tak membuat mereka menyadari dan memikirikan asal-muasal mereka dan akhir dari penciptaan. QS. As Syuara (26: 131-135). Mereka juga tak pernah memikirkan dari mana segala rezeki dan nikmat yang mereka rasakan. Puncak pemikiran dan kepintaran mereka hanya berujung pada penyembahan berhala. Lebih

${ }^{6}$ Ahmad Bahjah, Nabi-Nabi Allah, (Jakarta: Qisthi Press, 2012), h. 19 
para lagi, justru mereka berbuat kerusakan di muka bumi dengan jalan menghinakan orang yang lemah dan menzalimi rakyat jelata. ${ }^{7}$

Dalam bidang arsitek, disamping mereka memiliki bentuk fisikal yang besar dan kekar, mereka juga terkenal dengan perancangan pembagunan dan tata kota. QS. Al Fajr (89): 7. mereka membangun gedung-gedung yang kokoh untuk mereka nikmati, selain itu bangunan tersebut dijadikan benteng untuk menahan serangan kaum lain sekaligus dijadikan bangunan pengintai segala kegiatan diluar benteng yang dapat membahayakan. Kaum Aad juga terkenal dengan kepiawaiannya dalam hal siasat perang, sehingga musuh-musuhnya merasa ketakutan dan takluk sebelum berperang. Hal ini disebabkan oleh kejamnya kaum Aad kepada musuhnya. Mereka lebih suka menyiksa musuh yang tidak berdaya dengan berbagai siksaan yang diluar batas perikemanusiaan. ${ }^{8}$ Sehingga dari keadaan ini dapat disimpulkan bahwa kemerosotan akhlak yang merajalela pada kaum Aad yang menjadi pemicu terjadinya siklus pengutusan seorang nabi dan rasul kepada mereka, baik itu kemerosotan akhlah kepada tuhan dengan mengadakan tandingan penyembahan berubah berhala, maupun kemerosotan akhlak kepada sesama manusia dengan melakukan perbuatan zalim kepada musuh-musuhnya. Sebagaimana yang disebutkan dalam Suran as Syuaraa: 130, bahwa apabila kamu menyiksa maka kamu menyiksa dengan cara keji dan bengis.

${ }^{7}$ Ahmad Jadul Mawla dan Abu Al Fadl Ibrahim, Buku induk Kisah Alquran (terj) (Jakarta: Zaman, 2009) h..47-48 1995) h. 50

${ }^{8} \mathrm{Ny}$. Kholillah Marhijanto, Kisah Teladan 25 Nabi dan Rasul, (Surabaya: Arkola, 


\section{Misi dan Materi Dakwah Nabi Hud}

Nabi Hud diutus kepada saudaranya dari kaum Aad, untuk meluruskan aqidah mereka yang salah serta mengajarkan akhlah yang benar. Kedua poin tersebut menjadi misi utama dan materi dakwahdengan mengajarkan pentingnya menyembah Allah tanpa mempersekutukannya dengan sesuatu apapun, dan mengingatkan untuk tidak melakukakn penzaliman dan penganiayaan kepada golongan orang yang lemah, baik dari kalangan musuh ataupun bukan.Meskipun materi tersebut tidak diuraikan secara kompleks sebagaimana yang dikenal dalam pemilihan materi dakwah ajaran Islam. tetapi substansi dan esensi dari materi tersebut sudah dipraktekkan oleh nabi Hud. Abdul Karim Zaidan mengelompokkan materi dakwah dalam ajaran Islam secara garis besar terdiri dari berbagai bidang diantaranya:

a. Kepercayaan (tauhid atau Aqidah), yaitu peraturan yang mengatur dan menyangkut kepercayaan seperti terkandung dalam rukun iman

b. Etika (akhlak), yaitu peraturan yang mengatur perbuatan manusia menyangkut perbuatan-perbuatan yang harus dilakukan dan yang harus ditinggalkan

c. Ibadah, yaitu peraturan yang mengatur hubungan manusia dengan tuhannya secara baik dan benar

d. Muamalah, yaitu peraturan yang mengatur hubungan sesame manusia. ${ }^{9}$

\footnotetext{
1980), h. 65

${ }^{9}$ Abdul Karim Zaidan, Dasar-dasar Ilmu Dakwah, (Jakarta: Media Dakwah,
} 
5. Respon Kaum Aad terhadap Misi Nabi Hud

Telah disinggung sebelumnya, bahwa setiap nabi yang diturunkan pasti menjadi rahmat bagi kaumnya atau bagi zamannya. Hingga ketika nabi yang terakhir datang, maka beliau datang sebagai rahmat bagi seluruh alam. QS. Al Anbiya' (21): 107. Jika bukan karena nabi Muhammad, tiadalah akan diketahui kisah-kisah para nabi terdahulu dan realita kaumnya yang benar, karena kisah para nabi telah banyak diselewengkan sebelum diutusnya Muhammad Saw. ${ }^{10}$

Sebenarnya, respon kaum Aad dari dakwah nabi Hud merupakan pengulangan sejarah seperti apa yang terjadi pada nabi sebeumnya yaitu Nuh dan nabi-nabi yang akan datang sesudahnya. Tanpa harus menafikan adanya kelompok minoritas yang menerima dakwah para nabi yang mendapat pertolongan Allah ketika azab telah diturunkan. Respon para penolak dakwah nabi tersebut melalui proses dan memiliki jenjang pembangkangan yang bertingkat, bermula hanya sebatas menolak dan heran terhadap dakwah yang dianggapnya sesuatu hal yang baru tanpa ada respon yang lebih dan tanpa ada argumen atau alasan penolakan, kemudian tahap selanjutnya mengarah pada pencacian dan penghinaan kepada utusan Allah dengan mengatakannya seorang yang bodoh dan gila.

Kemudian pada tahap berikutnya pembangkangan mereka sudah disertai dengan respon keras dan biasanya akan mengeluarkan alasanalasannya yang identik dengan tradisi nenek moyang yang dipertahankan, hingga sampai pada tahap terakhir bentuk penolakan yang ditandai dengan kesombongan dengan menantang langsung sang pencipta untuk

${ }^{10}$ Ahmad Bahjah, h. 12 
mendatangkan bukti nyata ataukah azab yang telah dijanjikan. Tentunya, penolakan yang bervariatif itu disebabkan karena ajakan dan dakwah yang berulang-ulang ditujukan kepada mereka sebagai realisasi dari tugas utama seorang nabi sebagai pemberi peringatan. Sesuatu yang lumrah bila seseorang membenci orang lain, sementara orang lain itu tak hentihentinya mendekat kepadanya, maka akhirnya akan memancing rasa emosi dan memunculkan kemarahan hingga mengeluarkan kata-kata umpatan bahkan meminta sesuatu yang bersifat menantang.

\section{Balasan Allah Kepada Kaum Aad}

Tidak ada kaum yang dihancurkan oleh Allah secara tiba-tiba tanpa didahului dengan datang seorang utusan kepada mereka untuk memberi peringatan. Kehancuran yang ditimpakan pada suatu kaum, baik secara bertahap maupun tiba-tiba, ketika peringatan dan dakwah yang dibawa nabi Allah tidak mendapatkan tanggapan dan penerimaan dari kaum tersebut. Adapun balasan Allah atas pembangkangan kaum Aad dan memilih untuk tetap dalam kekafiran melalui dua tahapan. Tahap pertama balasan Allah berupa paceklik dan kekeringan yang melanda ladang dan kebun mereka, sehingga menimbulkan kekhawatiran terhadap hasil panen yang akan didapatkan. Sebagaimana yang disebutkan dalam QS. Hud (11): 52.

Dalam situasi seperti ini, Hud sebagai utusan Allah tetap mengajak kaumnya dan senantiasa memberikan peringatan sampai tiba saat Allah memberikan keputusanNya yang final yang berbentuk penghancuran secara total. Nabi Hud berusaha meyakinkan bahwa kekeringan itu adalah suatu permulaan balasan dari Allah yang dijanjikan.Ia berusaha membujuk bahwadia Allah masih lagi memberi kesempatan untuk sadar dari kesesatan dan kembali kepada jalan lurus, yaitu beriman kepadanya 
dan meninggalkan penyembahan berhala kemudian bertaubat dan memohon ampun kepada Nya, agar dengan demikian dapat diturunkan hujan yang lebat atas izinnya sehingga terhindar dari bahaya kelaparan yang mengancam. Akan tetapi karena kesombongannya yang menutupi mata hatinya,mereka justerumenganggap Hud sebagai pembawa janjijanji palsu, dan malahanmereka pergi menghadap kepada berhalaberhala untuk memohon perlindungan dari musibah kekeringan yang mereka hadapi.

Tahap kedua daripada balasan Allah dimulai dengan terlihatnya gumpalan awan hitam yang tebal di atas mereka yang disabutnya dengan sorak-sorai gembira, karena disangkanya gumpalan awan tersebut akan menurunkan hujan lebat dan memabasahi ladang dan kebun-kebun yang sudah lama mengalami kekeringan. Melihat sikap kaum Aad yang riang gembira itu, berkatalah nabi Hud dengan nada seakan akan mengejek bahwa: 'awan hitam tersebut bukanlah awan yang akan mendatangkan rahmat bagi kalian melainkan akan mendatangkan azab yang menghancurkan sebagai balasan terhadap apa yang telah ku janjikan dan kalian mendustakannya, dan juga sebagai bukti kebenaran yang senantiasa kalian menantangnya untuk diperlihatkan", sebagaimana yang disebutkan dalam QS. Al Ahqaf (46): 24-25. Maka beberapa saat kemudian, apa yang telah diramalkan oleh Hud menjadi kenyataan, bahwa awan hitam yang dikira akan menurunkan hujan tetapi tak kunjung turun, melainkan angin topan yang kencang disertai dengan bunyi gemuruh mengerikan yang justru datang menyapanya, hingga akhirnya melululantahkan segala apa yang mereka banggakan, mulai dari bangunan, harta kekayaan dan semua yang mengingkari dakwah nabi Hud. Mereka berlari tidak terarah mencari perlindungan, sementara nabi 
Hud dan kaumnya yang beriman merasa aman dalam lindungan Allahhingga azab itu menyapu bersih dan meratakan bangsa Aad dengan tanah, peristiwa itu ditimpahkan selama delapan hari tujuh malam. QS. Al Haqqah (69):7

\section{Temuan Arkeolog Peradaban Kaum Aad}

Pada awal tahun 1990 muncul keterangan pers dalam beberapa surat kabar terkemuka di dunia yang menyatakan dalam beberapa judulnya seperti "Kota Legenda Arabia yang Hilang Telah Ditemukan", "Kota Legenda Arabia Ditemukan" atau "Ubar, Atlantis di Padang Pasir."Banyak orang, yang sejak dahulu beranggapan bahwa kaum Aad sebagai-mana diceritakan dalam Alquran hanyalah sebuah legenda atau berang-gapan bahwa lokasi mereka tidak akan pernah ditemukan, tidak dapat menyembunyikan keheranan mereka atas penemuan ini. Penemuan kota ini, yang hanya disebutkan dalam cerita lisan Suku Badui, membangkit-kan minat dan rasa keingintahuan yang besar.

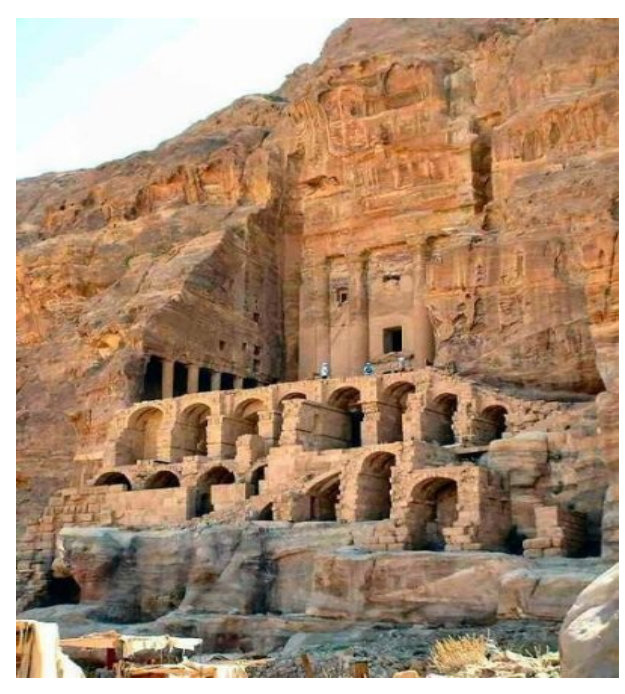

Dalam berbagai upaya yang dilakukan, salah seorang peneliti yang bernama Nicholas Clapp seorang arkeolog menyandarkan penelitiannya pada buku-buku sejarah arab yang merujuk pada keterangan Alquran dan karya peneliti Inggris bernama Bertram Thomas dengan judul Arabia Felix yang berarti Arabia yang beruntung.

Dalam keterangan Alquran sendiri, kejadian ini terjadi di Iram (Irama 
Dzatil Imad), salah satu kota disemenanjung Arabia. Kemudian beliau menelusuri jejak sebuah kota kuno dibagian selatan semenanjung Arabia (termasuk Yaman dan Oman), bernama Ubar yang disebutkan dalam dongeng suku badui. Dari sini ditemukan sejumlah fakta empirik, sejumlah bekas reruntuhan yang diyakini merupakan pilar-pilar dan bangunan menara yang dahulunya dimiliki kaum Aad dan Iram. ${ }^{11}$

Namun sejumlah peneliti lain mempersoalkan hubungan penemuan bukti bangunan tersebut dengan kaum Aad. Alasannya karena tidak ada catatan sejarah yang menyebutkan tentang suatu kaum yang telah memiliki kebudayaan begitu maju. Adapun jawaban yang dikemukan oleh Harun yahya bahwa 'seharusnya tidak terlalu mengherankan bila tidak ditemukan keberadaan kaum ini dalam berbagai catatan sejarah dan arsip-arsip peradaban lama. Alasannya adalah bahwa kaum ini tinggal di Arabia Selatan, sebuah daerah yang jauh dari kaum lain yang hidup di daerah Mesopotamia dan timur tengah, dan hanya memiliki hubungan yang terbatas dengan mereka. Sehingga komunikasi tertulis tidak lazim di daerah tersebut dan tidak sempat didokumentasikan dalam catatan sejarah. ${ }^{12}$

8. Ibrah yang dapat diambil dari Kisah Hud dan Kaumnya

Kisah umat terdahulu yang terdapat dalam Alquran merupakan salah satu pokok wahyu ilahi yang harus direnungkan. Berbagai peristiwa penghancuran umat terdahulu seharusnya menjadi peringatan bagi

11 Syahruddin el Fikri, Dari Banjir Nuh Hingga Bukit Thursina, (Jakarta: Republika, 2014, Cet III), h. 77-78

12 Harun Yahya, Jejak-Jejak Bangsa Terdahulu, terj. Shobrie Hardhi, tahun 2009. Tanpa nama penerbit, h. 51 
generasi berikutnya. Hampir semua kehancuran umat terdahulu dapat diidentifikasi melalui kajian arsip dan temuan arkeologis saat ini. Suatu kekeliruan besar jika hanya mengembangkan pendekatan historis dan ilmiah saat mengkaji jejak-jejak peristiwa di dalam Alquran tanpa mengambil pelajaran atau Ibrah darinya. ${ }^{13}$ Ibrah diambil dari akar kata ubur, yang berarti menyebrang, artinya ketika seseorang menjumpai kisah orang-orang dahulu dalam Alquran, seolah-olah ia menyeberang ke masa orang-orang dahulu, dan seolah-olah terlepas dari ikatan masa dan tempat serta terbebas dari belenggu realita.

diantara pelajaran yang dapat dipetik dari kisah Hud dan kaumnya, sebagai berikut:

a. Meneladani sifat dari nabi Hud;

Nabi Hud telah memberi contoh yang baik dan patut ditiru oleh juru dakwah dan para muballig. Beliau menghadapi kaumnya yang sombong dan keras kepala itu dengan penuh kesabaran, ketabahan dan kelapangan dada. Ia tidak membalas keburukan dengan keburukan, tapi ia menolaknya dengan kata-kata yang lembut yang menunjukkan bahawa beliau dapat menguasai emosinya dan tidak sampai kehilangan kesabaran. Hal tersebut dikarenakan ia hanya mengharapkan keridhaan allah dengan tidak menginginkan balasan ataupun ucapan terimah kasih. ${ }^{14} \mathrm{Nabi}$ Hud tidak marah ketika kaumnya menuduhnya sebagai orang bodoh dan gila. Ia dengan lemah lembut menolak tuduhan itu dengan hanya berucap:"tiadalah aku gila, melainkan hanya sebagai

${ }^{13}$ Harun Yahya, Fakta-fakta yang Mengungkap Hakikat hidup, terj (Bandung: Dzikra, 2000), h. 101

${ }^{14}$ Dr. Ali Fikri, Jejak-Jejak Para Nabi (terj.), (Yogyakarta: Pustaka Pelajar, 2003), h..32 
utusan Allah untuk memberikan nasehatan dan peringatan agar terhindar dari murka Allah. QS. Al A'raf (7): 67.

Kemudian dalam berdialog dengan kaumnya, Hud selalu berusaha mengetok hati nurani mereka dan mengajak mereka berfikir secara rasional dan menggunakan akal fikirannya dengan memberikan penjelasan akan nikmat-nikmat Allah atas mereka berupa harta dan anak keterunan, kebun-kebun dan sungai-sungai, dia Allah telah menambahkan kelebihan fisik dan menjadikan sebagai khalifah setelah kaum nabi Nuh ${ }^{15}$.QS. Al A'raf (7):69. Dalam artian nabi Hud mendatangkan bukti-bukti yang dapat diterima oleh akal mereka tentang kebenaran dakwahnya dan kesesatan jalan mereka. Dan beliua berusaha menegaskan bahwa tugasnya hanya sebatas menyampaikan dan mengingatkan, adapun hidayah itu adalah urusan Allah, dia akan memberinya kepada siapa yang dia kehendakiNya. .

b. Pengingkaran dan keangkuhan atas kekuasaan Allah adalah sumber kehancuran dan malapetaka

Alquran secara khusus menunjukkan kenyataan bahwa sebagian besar dari masyarakat yang dihancurkan tersebut memiliki tingkat peradaban yang tinggi. Di dalam Alquran, sifat-sifat dari kaum-kaum yang dihancurkan dijelaskan pada (QS. Qaaf, 50: 36). Dalam ayat tersebut, ditekankan secara khusus dua sifat dari kaum yang telah dihancurkan. Pertama, mereka "lebih besar kekuatannya". Artinya, masyarakatmasyarakat tersebut telah mencapai sistem birokrasi militer yang kuat dan disiplin, dan meraih kekuasaan di wilayah mereka dengan kekuatan.

15 Ibid., h. 32 
Kedua, masyarakat-masyarakat itu mendirikan kota-kota besar yang dicirikan dengan karya-karya arsitektur mereka. Patut diperhatikan bahwa kedua sifat ini dimiliki oleh peradaban zaman sekarang, yang telah membentuk sebuah kebudayaan dunia yang begitu luas melalui ilmu pengetahuan dan teknologi saat ini, serta telah mendirikan negara-negara yang tersentralisasi, kota-kota besar, namun mengingkari dan mengabaikan Allah, dengan melupakan bahwa semua itu dimungkinkan oleh kekuasan Allah. Namun, sebagaimana diungkapkan pada ayat di atas, peradaban yang mereka kembangkan tidak dapat menyelamatkan masyarakat-masyarakat tersebut, karena peradaban mereka berlandaskan pengingkaran terhadap Allah. Akhir dari peradaban saat ini pun tidak akan berbeda, selama ia berdasarkan kepada pengingkaran dan perilaku jahat di dunia. ${ }^{16}$

c. Meyakini keradaan dan kekuasaan Allah adalah sumber keselamatan

Manusia adalah makhluk yang lemah. banyak kejadian di alam semesta ini yang mengisyaratkan bahwa manusia adalah makhluk yang lemah. Alquran menerangkan bahwa betapa banyak kaum terdahulu yang lebih kuat, pun harus musnah ketika ditimpa bencana. Hanya Allah yang mempunyai kekuasaanuntuk mengatur segala apa yang ada di muka bumi. Dialah yang mempunya sifat kehendak untuk menyelamatkan ataukah menghancurkan suatu kaum. Karena dialah yang paling mengetahui segala urusan makhluknya, mana yang terbaik dan terburuk, maka dia mengutus nabi dan rasul untuk mengingatkan apa yang terbaik dan terburuk itu bagi hamba-hamabNya. Keadaan kaum Aad yang

${ }^{16}$ Harun Yahya, Jejak-Jejak Bangsa Terdahulu..., h. 11 
digambarkan dalam Alquran yang awalnya penuh dengan tumbuhtumbuhan dan perairan, berubah seketika dengan didatangkannya badai pasir yang mengubur semua peradaban yang telah ada. Semua hal ini adalah kehendak dan kuasa Allah.

d. Siklus kehidupan merupakan aturan Allah

Kaum Aad menjadi sesat, mengingkari agama tauhid dan akhirnya dibinasakan, lalu digantikan dengan umat lain ${ }^{17}$. Siklus pergantian ini juga berlaku bagi umat Muhammad, ketika Allah memperingatkan melalui firmannya dalam QS. Al Maidah (5): 54.

\section{Kesimpulan}

Alquran sebagai kitab petunjuk dapat memberikan informasi tentang sejarah umat terdahulu untuk kemudian dijadikan pelajaran hidup bagi umat-umat yang datang belakangan, khususnya umat Nabi Muhammad. Dari beberapa peristiwa kehancuran dalam sejarah Nabinabi yang telah digambarkan dalam Alquran, semuanya disebabkan karena ulah dan prilaku umat-umat mereka. Maka suatu kepastian dari sunnatullah untuk mendatangkan bencana akibat dari perbuatan mereka.

\section{Daftar Pustaka}

Bahjah, Ahmad.Nabi-Nabi Allah. Jakarta: Qisthi Press, 2012.

el Fikri,Syahruddin.Dari Banjir Nuh Hingga Bukit Thursina. Cet III. Jakarta: Republika, 2014.

Fikri, Ali.Jejak-Jejak Para Nabi.Yogyakarta: Pustaka Pelajar, 2003.

Ibn Kasir, Qishashul Quran, terj. Kisah Para Nabi, Karya. T.p.,T.t.

17 K.R.M.T.H Murdodiningrat, Kisah Teladan 25 Nabi dan Rasul, (Yogyakarta: Pustaka Pelajar, 2012), h. 298 
Sutrisno, Kisah dan Materi Dakwah Nabi Hud

K.R.M.T.H Murdodiningrat. Kisah Teladan 25 Nabi dan Rasul dalam Alquran. Yogyakarta: Pustaka Pelajar, 2012.

Marhijanto,Kholillah. Kisah Teladan 25 Nabi dan Rasul. Surabaya: Arkola, 1995.

Mawla, Ahmad Jadul, dan Abu Al Fadl Ibrahim, Buku Induk Kisah Alquran. Jakarta: Zaman, 2009

Shihab,Quraish. Wawasan Alquran.Cet XIII. Bandung: mizan, 1996.

Yahya,Harun. Jejak-Jejak Bangsa Terdahulu. terj. Shobrie Hardhi, T.p., 2009.

, Fakta-Fakta Yang Mengungkap Hakikat Hidup. Bandung: Dzikra, 2000.

Zaidan, Abdul Karim.Dasar-Dasar Ilmu Dakwah. Jakarta: Media Dakwah, 1980. 